\title{
Henriciella litoralis sp. nov., isolated from a tidal flat, transfer of Maribaculum marinum Lai et al. 2009 to the genus Henriciella as Henriciella aquimarina nom. nov. and emended description of the genus Henriciella
}

Correspondence Che Ok Jeon cojeon@cau.ac.kr

\author{
Se Hee Lee, ${ }^{1} \dagger$ Jae Kuk Shim, ${ }^{1} \dagger$ Jeong Myeong Kim, ${ }^{1}$ Hyung-Kyoon $\mathrm{Choi}^{2}$ \\ and Che Ok Jeon ${ }^{1}$
'Department of Life Science and Research Center for Biomolecules and Biosystems, Chung-Ang University, Seoul 156-756, Republic of Korea
${ }^{2}$ College of Pharmacy, Chung-Ang University, Seoul 156-756, Republic of Korea

\begin{abstract}
A Gram-staining-negative, strictly aerobic bacterium, designated strain $\mathrm{SD}^{\top}{ }^{\top}$, was isolated from a tidal flat of the Yellow Sea, South Korea. Cells were non-spore-forming rods that showed catalase- and oxidase-positive reactions. Growth of strain SD10 $10^{\top}$ was observed at $15-40{ }^{\circ} \mathrm{C}$ (optimum, 25-30 ${ }^{\circ} \mathrm{C}$ ), at $\mathrm{pH}$ 6.0-9.0 (optimum, $\mathrm{pH}$ 6.5-8.5) and in the presence of 1-10\% $(\mathrm{w} / \mathrm{v}) \mathrm{NaCl}$. Strain SD10 $0^{\top}$ contained ubiquinone-10 (Q-10) as a major isoprenoid quinone and $\mathrm{C}_{18: 1} \omega 7 c(39.3 \%), \mathrm{C}_{16: 0}(20.2 \%), \mathrm{C}_{17: 0}(8.9 \%)$ and $\mathrm{C}_{17: 1} \omega 6 c(8.1 \%)$ as major fatty acids. The cellular polar lipids were identified as phosphatidylglycerol, monoglycosyldiglyceride, glucuronopyranosyldiglyceride and two unidentified glycolipids. The $\mathrm{G}+\mathrm{C}$ content of the genomic DNA was 55.2 mol\%. Based on 16S rRNA gene sequence similarities, the strain was most closely related to Henriciella marina $1 s 04^{\top}$ and Maribaculum marinum $\mathrm{P}_{3} 8^{\top}$, with similarities of 97.8 and $97.0 \%$, respectively. The DNA-DNA relatedness between strain SD10 ${ }^{\top}$ and H. marina Iso $4^{\top}$ was $12.0 \pm 3.2 \%$. A phylogenetic analysis based on $16 \mathrm{~S}$ rRNA gene sequences showed that $M$. marinum $\mathrm{P} 38^{\top}$ and $H$. marina 1 so $4^{\top}$ formed a monophyletic cluster and that their 16S rRNA gene sequence similarity was 98.1\%. DNA-DNA hybridization between $H$. marina Iso $4^{\top}$ and $M$. marinum LMG $24711^{\top}$ was $22.9 \pm 2.7 \%$, indicating that the two strains belong to separate species. On the basis of chemotaxonomic data and molecular properties, we propose that strain SD10 ${ }^{\top}$ represents a novel species of the genus Henriciella, for which the name Henriciella litoralis sp. nov. is proposed. The type strain is SD10 ${ }^{\top}\left(=\mathrm{KACC} 13700^{\top}=\mathrm{DSM}\right.$ $22014^{\top}$ ). In addition, we propose to transfer Maribaculum marinum Lai et al. 2009 to the genus Henriciella as Henriciella aquimarina nom. nov. (type strain $\mathrm{P}_{3} 8^{\top}=\mathrm{CCTCC} A B 208227^{\top}=\mathrm{LMG}^{\mathrm{A}}$ $24711^{\top}=\operatorname{MCCC} 1 \mathrm{~A}^{\top} 1086^{\top}$ ), and we present an emended description of the genus Henriciella.
\end{abstract}

The family Hyphomonadaceae was proposed by Lee et al. (2005a) as a member of the order Rhodobacterales based on 16S rRNA gene sequence analyses. Members of the family have been isolated from various marine habitats such as surface seawater, brackish water, the deep sea, Antarctic seawater, hydrothermal vents and a culture of dinoflagellates

†These authors contributed equally to this work.

Abbreviations: GUDG, glucuronopyranosyldiglyceride; MGDG, monoglycosyldiglyceride; PG, phosphatidylglycerol.

The GenBank/EMBL/DDBJ accession number for the 16S rRNA gene sequence of strain $\mathrm{SD} 10^{\top}$ is $\mathrm{FJ} 230835$.

Two supplementary figures and a supplementary table are available with the online version of this paper.
(Moore et al., 1984; Abraham et al., 2002; Strömpl et al., 2003; Lee et al., 2007; Kang \& Lee, 2009a, b). Among them, the genus Henriciella belonging to the family Hyphomonadaceae was first described by Quan et al. (2009) with the single species Henriciella marina, isolated from seawater. The coasts of the Yellow Sea around the Korean peninsula consist of vast tidal flats known as getbol, which are marine habitats that possess valuable biological resources such as micro-organisms and marine animals and play very important roles in the restoration of coastal ecosystems. Therefore, efforts have been made in our laboratory to isolate and characterize members of the bacterial community of tidal flats of the Yellow Sea (Kim et al., 2010). Here, we describe the taxonomic 
characterization of a novel species belonging to the genus Henriciella using a polyphasic approach. Recently, Maribaculum marinum was described as the first member of a new genus of the family Hyphomonadaceae (Lai et al., 2009). Phylogenetic analysis based on $16 \mathrm{~S}$ rRNA gene sequence data showed that $M$. marinum $\mathrm{P} 38^{\mathrm{T}}$ formed a phylogenetic lineage with $H$. marina Iso $^{\mathrm{T}}$, with $98.1 \%$ $16 \mathrm{~S}$ rRNA gene sequence similarity. Therefore, we also propose the transfer of Maribaculum marinum to the genus Henriciella.

Strain $\mathrm{SD} 10^{\mathrm{T}}$ was isolated from a tidal flat at Taean using a previously described procedure with some modifications (Kim et al., 2008). Briefly, a sediment sample was serially diluted with marine broth (MB; Difco), spread on marine agar 2216 (MA; Difco) plates and incubated at $25{ }^{\circ} \mathrm{C}$ for 5 days. Colonies were selected randomly and crude lysates containing genomic DNA from the colonies were prepared by boiling a small amount of cell material from colonies in $100 \mu \mathrm{l}$ of $5 \%$ Chelex 100 solution (Bio$\mathrm{Rad}$ ) for $10 \mathrm{~min}$ and centrifugation at $15000 \mathrm{~g}$ for 10 min. PCR amplification of the 16S rRNA gene from the crude lysates was performed using universal primers as described previously (Lu et al., 2006). The amplicons were double-digested with HaeIII and HhaI. Restriction fragment length polymorphism (RFLP) patterns were analysed on $2.5 \%$ MetaPhore agarose gels (BioWhittaker) and representative PCR products containing distinct RFLP patterns were sequenced. The resulting $16 \mathrm{~S}$ rRNA gene sequences were analysed using the BLAST program (http://www.ncbi.nlm.nih.gov/BLAST/) in GenBank. From the analysis, strain $\mathrm{SD} 10^{\mathrm{T}}$, a novel member of the genus Henriciella, was selected for phenotypic and phylogenetic analysis. The strain was routinely grown aerobically on MA at $25{ }^{\circ} \mathrm{C}$ for 3 days, except where indicated otherwise. The strain was stored at $-80{ }^{\circ} \mathrm{C}$ in $\mathrm{MB}$ supplemented with $10 \%(\mathrm{v} / \mathrm{v})$ glycerol for preservation. H. marina $\mathrm{Iso}^{\mathrm{T}}{ }^{\mathrm{T}}$, a gift from Dr Jin-Woo Bae, and M. marinum LMG $24711^{\mathrm{T}}$, purchased from BCCM/LMG (Belgium), were used as reference strains for DNA-DNA hybridization, phenotypic characterization and fatty acid analysis.

The 16S rRNA gene sequence (1332 nt) of strain SD10 ${ }^{\mathrm{T}}$ was compared with available $16 \mathrm{~S}$ rRNA gene sequences from GenBank using the BLAST program to determine an approximate phylogenetic affiliation. Sequence similarity between the isolate and related bacteria was evaluated using the Nucleotide Similarity Search program at the EzTaxon server (http://147.47.212.35:8080; Chun et al., 2007) and aligned with sequences of closely related members by using the CLUSTAL $\mathrm{W}$ software program (Thompson et al., 1994). Phylogenetic trees were constructed by using the neighbour-joining, maximumlikelihood and maximum-parsimony algorithms available in the PHYLIP software, version 3.6 (Felsenstein, 2002). The resulting tree topologies were evaluated using a bootstrap analysis based on 1000 resampled datasets with the PHYLIP package.
Phylogenetic analysis based on 16S rRNA gene sequences indicated that strain $\mathrm{SD} 10^{\mathrm{T}}$ formed a tight phyletic lineage with $H$. marina $\mathrm{Iso}^{\mathrm{T}}$ and $M$. marinum $\mathrm{P} 38^{\mathrm{T}}$ with a bootstrap value of $100 \%$ (Fig. 1). The overall topologies of the maximum-likelihood and maximum-parsimony trees were essentially the same as that of the neighbour-joining tree (not shown). Comparative 16S rRNA gene sequence analysis showed that strain SD10 ${ }^{\mathrm{T}}$ was closely related to $H$. marina $\mathrm{Iso}^{\mathrm{T}}$ and $M$. marinum $\mathrm{P} 38^{\mathrm{T}}$, with similarities of 97.8 and $97.0 \%$, respectively, and the sequence similarity to other closely related taxa was less than $94.8 \%$. The phylogenetic analysis also showed that M. marinum $\mathrm{P} 38^{\mathrm{T}}$ and H. marina Iso $4^{\mathrm{T}}$ formed a monophyletic cluster and that their $16 \mathrm{~S}$ rRNA gene sequence similarity was $98.1 \%$.

DNA-DNA hybridization was carried out to evaluate the level of DNA relatedness between strain $\mathrm{SD}^{\mathrm{T}}$ and $H$. marina $\mathrm{Iso}^{\mathrm{T}}$ and between $H$. marina $\mathrm{Iso}^{\mathrm{T}}$ and $M$. marinum LMG $24711^{\mathrm{T}}$. The concentrations of the extracted genomic DNAs were measured at $260 \mathrm{~nm}$ using an ELISA reader equipped with a Take3 Multi-Volume plate (SynergyMx; BioTek). The DNA samples were fragmented with HaeIII for slot hybridization. The digested DNAs were diluted serially and, after denaturation using $\mathrm{NaOH}$ solution and heating $\left(80{ }^{\circ} \mathrm{C}\right)$, different amounts of the fragmented DNA $(0,8,16,24,32,40,60,80,120$, $160 \mathrm{ng}$ ) were blotted onto Hybond-N + nylon membranes (Amersham Pharmacia Biotech) in three replicates. Each DNA $(4 \mu \mathrm{g})$ was used individually as a labelled probe for cross-hybridization (Park et al., 2007). Random-primed DNA labelling with digoxigenin (DIG)-dUTP and detection of hybrids by enzyme immunoassay on nylon membrane were performed in triplicate using the DIG High Prime DNA Labelling kit (Roche Applied Science) according to the manufacturer's instructions and standard procedures (Sambrook \& Russell, 2001). Hybridization signals were captured and analysed with Bio-Rad Quantity One software (version 4.62). The signal produced by hybridization of the probe to the homologous target DNA was taken to be $100 \%$, and signal intensities by selfhybridization of the series of dilutions were used for calculation of the levels of DNA relatedness between strain $\mathrm{SD} 10^{\mathrm{T}}$ and $H$. marina Iso $4^{\mathrm{T}}$ and between $H$. marina Iso $4^{\mathrm{T}}$ and M. marinum LMG $24711^{\mathrm{T}}$ (Lee et al., 2005b). Hybridization experiments were always confirmed by cross-hybridization. DNA-DNA relatedness between strain SD $10^{\mathrm{T}}$ and $H$. marina $\mathrm{Iso}^{\mathrm{T}}$ and between $H$. marina $\mathrm{Iso}^{\mathrm{T}}$ and M. marinum LMG $24711^{\mathrm{T}}$ was $12.0 \pm 3.2$ and $22.9 \pm 2.7 \%$, respectively, clearly below the $70 \%$ threshold generally accepted for species delineation (Rosselló-Mora \& Amann, 2001).

Physiological characteristics of strain $\mathrm{SD} 10^{\mathrm{T}}$ were examined by growing the isolate at $5-40{ }^{\circ} \mathrm{C}\left(\right.$ at $5{ }^{\circ} \mathrm{C}$ intervals) on $\mathrm{MA}$ and at $\mathrm{pH} 4.0-9.5$ (at $0.5 \mathrm{pH}$ unit intervals) in $\mathrm{MB}$. The $\mathrm{pH}$ was adjusted prior to sterilization by the addition of $\mathrm{HCl}$ or $\mathrm{NaOH}$ and measured again after sterilization. Gram staining was performed using a bioMérieux Gram stain kit according to the instructions of the manufacturer. 


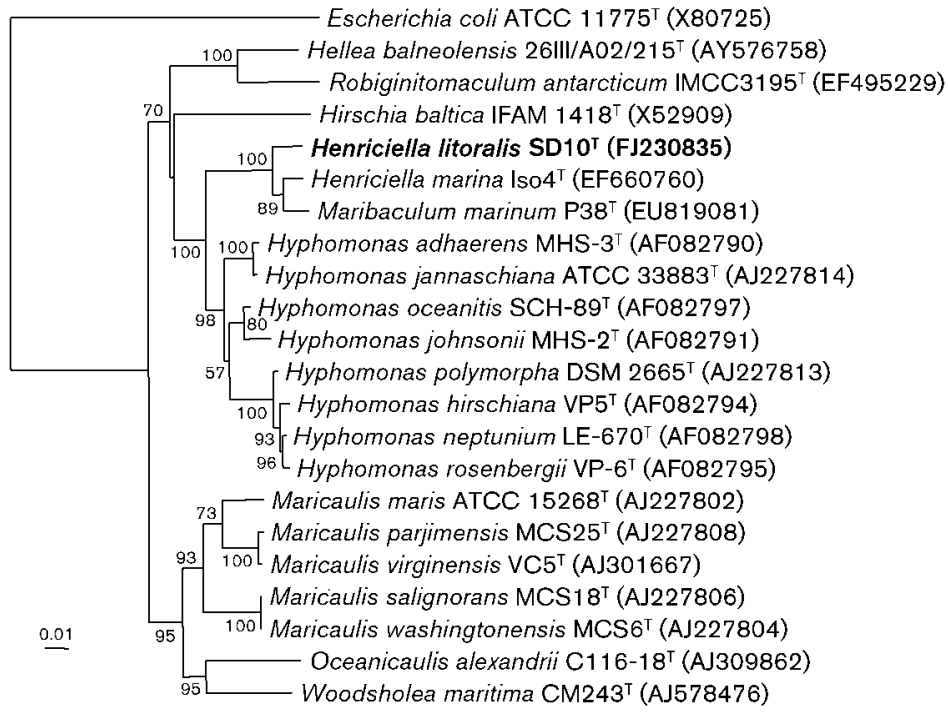

Fig. 1. Neighbour-joining tree based on nearly complete 16S rRNA gene sequences showing the phylogenetic relationships of strain SD10 ${ }^{\top}$, M. marinum $\mathrm{P} 38^{\mathrm{T}}$ and related taxa. Bootstrap values are shown at branch nodes based on 1000 resamplings; only values over $50 \%$ are given. The sequence of Escherichia coli ATCC $11775^{\top}$ was used as an outgroup. Bar, 0.01 changes per nucleotide position.
Cell morphology, the formation of flagella and hyphae and motility of strain $\mathrm{SD} 10^{\mathrm{T}}$ were studied using phase-contrast microscopy and transmission electron microscopy (JEM1010; JEOL) as described previously (Jeon et al., 2004). $\mathrm{NaCl}$ requirements and tolerance were determined in nutrient broth supplemented with modified artificial seawater $[0-15 \%(\mathrm{w} / \mathrm{v}) \mathrm{NaCl}$ (in increments of $1 \%$ ), $5.94 \mathrm{~g} \mathrm{MgSO}_{4} \cdot 7 \mathrm{H}_{2} \mathrm{O}, 4.53 \mathrm{~g} \mathrm{MgCl}_{2} \cdot 6 \mathrm{H}_{2} \mathrm{O}, 0.64 \mathrm{~g} \mathrm{KCl}$ and $1.3 \mathrm{~g} \mathrm{CaCl}_{2}$ per litre]. Oxidase activity was tested by oxidation of $1 \%(\mathrm{w} / \mathrm{v})$ tetramethyl-p-phenylenediamine (Merck) and catalase activity was evaluated by the production of oxygen bubbles in $3 \%(\mathrm{v} / \mathrm{v})$ aqueous hydrogen peroxide solution. Nitrate reduction was tested according to the method of Lányí (1987). Anaerobic growth was assessed on MA under anaerobic conditions (with $4-10 \% \mathrm{CO}_{2}$ ) using the GasPak Plus system (BBL) at $25{ }^{\circ} \mathrm{C}$ for 20 days. Additional enzyme activities and biochemical features and the utilization of carbon sources of strain $\mathrm{SD} 10^{\mathrm{T}}$ and reference strains were determined by using API $20 \mathrm{NE}$ and API ZYM strips (bioMérieux) and the GN2 MicroPlate system (Biolog) at $25{ }^{\circ} \mathrm{C}$ based on the manufacturers' instructions.

When tested on MA, growth of strain $\mathrm{SD} 10^{\mathrm{T}}$ was observed at $15-40{ }^{\circ} \mathrm{C}$ (optimum, $25-30{ }^{\circ} \mathrm{C}$ ), at $\mathrm{pH}$ 6.0-9.0 (optimum $\mathrm{pH} 6.5-8.5)$ and in the presence of $1-10 \%(\mathrm{w} / \mathrm{v})$ $\mathrm{NaCl}$ (optimum, 2-5\%). Bacterial cells were Gramstaining-negative, strictly aerobic, motile rods (0.4$0.6 \mu \mathrm{m}$ wide and $0.8-2.8 \mu \mathrm{m}$ long) with a single polar flagellum (Supplementary Fig. S1, available in IJSEM Online). Some of these properties are in accordance with the characteristics of members of the genus Henriciella, whereas others allow the differentiation of strain SD10 ${ }^{\mathrm{T}}$ from closely related Henriciella species (Table 1, Supplementary Table S1).

Isoprenoid quinones were analysed using an HPLC (model LC-20A; Shimadzu) equipped with a diode array detector
(SPD-M20A; Shimadzu) and a reversed-phase column $(250 \times 4.6 \mathrm{~mm}$ Kromasil; Akzo Nobel) as described by Komagata \& Suzuki (1987). For analysis of fatty acid methyl esters, cells of strain SD10 ${ }^{\mathrm{T}}$ were harvested from MA plates after incubation at $25{ }^{\circ} \mathrm{C}$ for 3 days. Analysis of fatty acid methyl esters was performed according to the instructions of the Microbial Identification System (MIDI; Microbial ID, Inc.). Polar lipids were determined by TLC as described by Minnikin et al. (1977). The DNA G +C content of strain $\mathrm{SD} 10^{\mathrm{T}}$ was determined using an HPLC fitted with a reversed-phase column (GROM-SIL 100 ODS-2FE; GROM) according to the method of Tamaoka \& Komagata (1984). The major respiratory lipoquinone of strain $\mathrm{SD} 10^{\mathrm{T}}$ was ubiquinone $10(\mathrm{Q}-10)$. The cellular polar lipids were identified as phosphatidylglycerol (PG), monoglycosyldiglyceride (MGDG), glucuronopyranosyldiglyceride (GUDG) and two unidentified glycolipids (GL1 and GL2) (Supplementary Fig. S2). Among these polar lipids, the presence of MGDG and GUDG appears to be a characteristic signature for members of the family Hyphomonadaceae, together with the absence of phosphatidylethanolamine and phosphatidylcholine (Alain et al., 2008; Kang \& Lee, 2009a). The major cellular fatty acids ( $>8 \%$ of the total fatty acids) were $\mathrm{C}_{18: 1} \omega 7 c(39.3 \%), \mathrm{C}_{16: 0}(20.2 \%), \mathrm{C}_{17: 0}(8.9 \%)$ and $\mathrm{C}_{17: 1} \omega 6 c(8.1 \%)$ (Table 2). This profile is similar to those of the phylogenetically related strains $H$. marina Iso $^{\mathrm{T}}$ and $M$. marinum LMG $24711^{\mathrm{T}}$, but differs in the proportions of some components. For example, fatty acid $\mathrm{C}_{12: 0} 3-\mathrm{OH}$ was not detected from strain $\mathrm{SD} 10^{\mathrm{T}}$, whereas it was detected from $H$. marina Iso $^{\mathrm{T}}$ and M. marinum LMG $24711^{\mathrm{T}}$. The $\mathrm{G}+\mathrm{C}$ content of strain $\mathrm{SD} 10^{\mathrm{T}}$ was $55.2 \mathrm{~mol} \%$. The major lipoquinone, major fatty acids and $\mathrm{G}+\mathrm{C}$ content were in accordance with those of members of the genus Henriciella (Quan et al., 2009).

The physiological, biochemical and phylogenetic properties of strain $\mathrm{SD}^{\mathrm{T}}{ }^{\mathrm{T}}$ support its assignment to a novel species within the genus Henriciella, for which the name 
Table 1. Phenotypic characteristics of strain $\mathrm{SD}_{10}{ }^{\top}$ and type strains of related species

Strains: 1, strain $\mathrm{SD}^{\mathrm{T}}{ }^{\mathrm{T}}$ (data from this study); 2, H. marina Iso $4^{\mathrm{T}}$ (unless indicated, data from Quan et al., 2009); 3, M. marinum LMG $24711^{\mathrm{T}}$ (unless indicated, data from Lai et al., 2009). All strains are positive for the following characteristics: division by binary fission, oxidase and catalase activities, the presence of flagella, alkaline phosphatase $^{\star}$, esterase $(\mathrm{C} 4)^{\star}$, esterase lipase $(\mathrm{C} 8)^{\star}$, lipase $(\mathrm{C} 14)^{\star}$, leucine arylamidase $e^{\star}$ valine arylamidase ${ }^{\star}$, cystine arylamidase $^{\star}$, $\operatorname{trypsin}^{\star}, \alpha$-chymotrypsin ${ }^{\star}$ and acid phosphatase ${ }^{\star}$ (API ZYM). All strains are negative for the following characteristics: Gram staining, prostheca formation, nitrate reduction, indole production, glucose acidification $^{\star}$, arginine dihydrolase ${ }^{\star}$, sporulation and growth at $4{ }^{\circ} \mathrm{C}$. + , Positive; - , negative; $\mathrm{w}$, weakly positive; ND, no data available.

\begin{tabular}{|c|c|c|c|}
\hline Characteristic & 1 & 2 & 3 \\
\hline Isolation source & Tidal flat & Seawater & Seawater \\
\hline Colony colour $\dagger$ & $\mathrm{Y}$ & TWH & G \\
\hline Cell shape $\ddagger$ & $\mathrm{O} / \mathrm{R}$ & $\mathrm{O} / \mathrm{R}$ & $\mathrm{O} / \mathrm{SR}$ \\
\hline Hypha formation & - & + & ND \\
\hline \multicolumn{4}{|l|}{ Growth at/in: } \\
\hline $40{ }^{\circ} \mathrm{C}$ & + & - & + \\
\hline $15 \% \mathrm{NaCl}$ & - & + & - \\
\hline Hydrolysis of aesculin & + & $-{ }^{\star}$ & $-{ }^{\star}$ \\
\hline \multicolumn{4}{|l|}{ Enzyme activities (API ZYM) } \\
\hline $\begin{array}{l}\text { Naphthol-AS-BI } \\
\text { phosphohydrolase }\end{array}$ & $\mathrm{w}$ & $+^{*}$ & $+^{*}$ \\
\hline$\alpha$-Glucosidase & $\mathrm{w}$ & $+^{*}$ & $+^{*}$ \\
\hline$\beta$-Glucosidase & $\mathrm{w}$ & $-{ }^{*}$ & $-{ }^{*}$ \\
\hline \multicolumn{4}{|l|}{ Carbon utilization (Biolog GN2) } \\
\hline Tween 80 & - & $+^{*}$ & $-{ }^{*}$ \\
\hline L-Arabinose & + & $+^{*}$ & $-{ }^{\star}$ \\
\hline D-Fructose & + & $-*$ & $+^{*}$ \\
\hline$\alpha$-D-Glucose & - & $-{ }^{\star}$ & $+^{*}$ \\
\hline Raffinose & + & $-{ }^{\star}$ & $-{ }^{\star}$ \\
\hline Sucrose & - & $+^{*}$ & $+^{*}$ \\
\hline Glycerol & + & $-*$ & $-^{\star}$ \\
\hline DNA G $+C$ content $(\mathrm{mol} \%)$ & 55.2 & 56.2 & 61.0 \\
\hline
\end{tabular}

${ }^{\star}$ Data from this study $\left(25{ }^{\circ} \mathrm{C}\right)$.

$\dagger_{\mathrm{G}}$, Grey; TwH, translucent white; Y, yellow.

$\ddagger$ O, Ovoid; R, rod; SR, short rod.

Henriciella litoralis sp. nov. is proposed. In addition, we propose the transfer of Maribaculum marinum to the genus Henriciella as Henriciella aquimarina nom. nov. and we provide an emended description of the genus Henriciella.

\section{Description of Henriciella litoralis sp. nov.}

Henriciella litoralis (li.to.ra'lis. L. fem. adj. litoralis of or belonging to the seashore).

Cells are Gram-negative, strictly aerobic, motile rods (0.4$0.6 \mu \mathrm{m}$ wide and $0.8-2.8 \mu \mathrm{m}$ long) with a polar flagellum. Colonies on MA are yellow, convex and round with entire margins. Growth occurs at $15-40{ }^{\circ} \mathrm{C}$ (optimum, 25$30{ }^{\circ} \mathrm{C}$ ), at $\mathrm{pH}$ 6.0-9.0 (optimum, $\mathrm{pH} 6.5-8.5$ ) and in the presence of 1-10\% (w/v) $\mathrm{NaCl}$ (optimum, 2-5\%). Division mode is binary fission. Catalase- and oxidase-positive. In the API 20NE kit, negative for nitrate reduction, indole production, glucose acidification and arginine dihydrolase activity and for assimilation of D-glucose, L-arabinose, Dmannose, maltose, D-mannitol, malic acid, potassium gluconate, $\mathrm{N}$-acetylglucosamine, capric acid, adipic acid, trisodium citrate and phenylacetic acid. Aesculin is hydrolysed. Urea and gelatin are not hydrolysed. In the API ZYM kit, alkaline phosphatase, esterase (C4), esterase lipase (C8), lipase (C14), leucine arylamidase, valine arylamidase, cystine arylamidase, trypsin, $\alpha$-chymotrypsin and acid phosphatase activities are present and weak enzymic activities are observed for naphthol-AS-BIphosphohydrolase, $\alpha$-glucosidase and $\beta$-glucosidase, but $\beta$-glucuronidase, $N$-acetyl- $\beta$-glucosaminidase, $\beta$-galactosidase, $\alpha$-fucosidase, $\alpha$-galactosidase, $\beta$-glucuronidase and $\alpha$ mannosidase are absent. Positive for utilization of Biolog GN2 MicroPlate system substrates dextrin, $N$-acetyl-Dgalactosamine, $\mathrm{N}$-acetyl-D-glucosamine, L-arabinose, Dfructose, L-fucose, D-galactose, myo-inositol D-mannose, methyl $\beta$-D-glucoside, raffinose, L-rhamnose, turanose, acetic acid, cis-aconitic acid, citric acid, D-galacturonic acid, D-gluconic acid, D-glucuronic acid, $\beta$-hydroxybutyric acid, $\gamma$-hydroxybutyric acid, quinic acid, D-saccharic acid, succinic acid, L-alaninamide, D- and L-alanine, L-alanyl glycine, L-aspartic acid, glycyl L-aspartic acid, glycyl L-glutamic acid, L-ornithine, L-serine, L-threonine, inosine, uridine, phenylethylamine, glycerol, DL- $\alpha$-glycerol phosphate and D-glucose 6-phosphate. Other organic substrates included in the Biolog GN2 microplate are not oxidized. The major isoprenoid quinone is Q-10. Contains PG, MGDG, GUDG and two unidentified glycolipids as polar lipids. The major cellular fatty acids are $\mathrm{C}_{18: 1} \omega 7 c, \mathrm{C}_{16: 0}, \mathrm{C}_{17: 0}$ and $\mathrm{C}_{17: 1} \omega 6 c$. The DNA G + C content of the type strain is $55.2 \mathrm{~mol} \%$ (HPLC).

The type strain is $\mathrm{SD} 10^{\mathrm{T}}\left(=\mathrm{KACC} 13700^{\mathrm{T}}=\mathrm{DSM} 22014^{\mathrm{T}}\right)$, which was isolated from a tidal flat of the Taean coast in South Korea.

\section{Description of Henriciella aquimarina (Lai et al. 2009) nom. nov.}

Henriciella aquimarina (a.qui.ma.ri'na. L. fem. n. aqua water; L. fem. adj. marina of or belonging to the sea; N.L. fem. adj. aquimarina from seawater).

Basonym: Maribaculum marinum Lai et al. 2009.

The description is as given for Maribaculum marinum by Lai et al. (2009). The type strain is $\mathrm{P} 38^{\mathrm{T}}$ (=CCTCC $\mathrm{AB}$ $208227^{\mathrm{T}}=$ LMG $24711^{\mathrm{T}}=$ MCCC $1 \mathrm{~A} 01086^{\mathrm{T}}$ ).

\section{Emended description of the genus Henriciella Quan et al. 2009}

The description of the genus Henriciella is as given by Quan et al. (2009) with the following amendments. The 
Table 2. Cellular fatty acid compositions of strain $\mathrm{SD}_{10}^{\top}, H$. marina Iso $4^{\top}$ and M. marinum LMG $24711^{\top}$

Strains: 1 , strain $\mathrm{SD} 10^{\mathrm{T}}$; 2. H. marina $\mathrm{Iso}^{\mathrm{T}}$; 3. M. marinum LMG $24711^{\mathrm{T}}$. All data were obtained in this study after growth on MA at $25{ }^{\circ} \mathrm{C}$ for 3 days. Data are expressed as percentages of total fatty acids; fatty acids amounting to less than $0.5 \%$ in all strains are not shown. tr, Trace amount $(<0.5 \%)$; - , not detected.

\begin{tabular}{|c|c|c|c|}
\hline Fatty acid & 1 & 2 & 3 \\
\hline \multicolumn{4}{|l|}{ Saturated } \\
\hline $\mathrm{C}_{15: 0}$ & 2.1 & 4.5 & 1.4 \\
\hline $\mathrm{C}_{16: 0}$ & 20.2 & 9.3 & 20.6 \\
\hline $\mathrm{C}_{17: 0}$ & 8.9 & 4.5 & 4.6 \\
\hline $\mathrm{C}_{18: 0}$ & 2.1 & $\operatorname{tr}$ & 2.7 \\
\hline $\mathrm{C}_{20: 0}$ & 1.7 & 1.2 & 3.3 \\
\hline \multicolumn{4}{|l|}{ Hydroxy } \\
\hline $\mathrm{C}_{12: 1} 3-\mathrm{OH}$ & - & 0.8 & - \\
\hline $\mathrm{C}_{12: 0} 3-\mathrm{OH}$ & - & 2.5 & 4.6 \\
\hline $\mathrm{C}_{18: 1} 2-\mathrm{OH}$ & - & - & 2.0 \\
\hline \multicolumn{4}{|l|}{ Branched } \\
\hline iso- $\mathrm{C}_{17: 0}$ & $\operatorname{tr}$ & 0.7 & - \\
\hline iso- $\mathrm{C}_{17: 0} 3-\mathrm{OH}$ & - & 1.5 & - \\
\hline \multicolumn{4}{|l|}{ Unsaturated } \\
\hline $\mathrm{C}_{15: 1} \omega 8 c$ & - & 0.7 & - \\
\hline $\mathrm{C}_{16: 1} \omega 5 c$ & 6.2 & 3.3 & 6.4 \\
\hline $\mathrm{C}_{17: 1} \omega 6 c$ & 8.1 & 8.9 & 3.3 \\
\hline $\mathrm{C}_{17: 1} \omega 8 c$ & 5.0 & 10.6 & 3.5 \\
\hline $\mathrm{C}_{18: 1} \omega 5 c$ & 2.1 & 1.2 & 0.9 \\
\hline $\mathrm{C}_{18: 1} \omega 7 c$ & 39.3 & 45.0 & 36.5 \\
\hline 11-Methyl $\mathrm{C}_{18: 1} \omega 7 c$ & 2.9 & 0.6 & 8.3 \\
\hline \multicolumn{4}{|l|}{ Cyclopropane acids } \\
\hline $\mathrm{C}_{19: 0}$ cyclo $\omega 8 \mathrm{c}$ & - & - & 1.3 \\
\hline \multicolumn{4}{|l|}{ Summed features ${ }^{\star}$} \\
\hline Summed feature 3 & $\operatorname{tr}$ & 2.2 & 0.7 \\
\hline
\end{tabular}

${ }^{\star}$ Summed features represent groups of two or three fatty acids that could not be separated by GLC with the MIDI system. Summed feature 3 contained $\mathrm{C}_{16: 1} \omega 7 c$ and/or iso- $\mathrm{C}_{15: 0} 2-\mathrm{OH}$.

major fatty acid is $\mathrm{C}_{18: 1} \omega 7 c$. The DNA G+C content is 55.2-62.0 $\mathrm{mol} \%$.

\section{Acknowledgements}

This research was supported by a Chung-Ang University Research Scholarship Grant in 2009.

\section{References}

Abraham, W. R., Strömpl, C., Bennasar, A., Vancanneyt, M., Snauwaert, C., Swings, J., Smit, J. \& Moore, E. R. B. (2002). Phylogeny of Maricaulis Abraham et al. 1999 and proposal of Maricaulis virginensis sp. nov., $M$. parjimensis sp. nov., M. washingtonensis sp. nov. and M. salignorans sp. nov. Int J Syst Evol Microbiol 52, 2191-2201.

Alain, K., Tindall, B. J., Intertaglia, L., Catala, P. \& Lebaron, P. (2008). Hellea balneolensis gen. nov., sp. nov., a prosthecate alphaproteobacterium from the Mediterranean Sea. Int J Syst Evol Microbiol 58, 2511-2519.
Chun, J., Lee, J. H., Jung, Y., Kim, M., Kim, S., Kim, B. K. \& Lim, Y. W. (2007). EzTaxon: a web-based tool for the identification of prokaryotes based on $16 \mathrm{~S}$ ribosomal RNA gene sequences. Int J Syst Evol Microbiol 57, 2259-2261.

Felsenstein, J. (2002). PHYLIP (phylogeny inference package), version 3.6a. Distributed by the author. Department of Genome Sciences, University of Washington, Seattle, USA.

Jeon, C. O., Park, W., Ghiorse, W. C. \& Madsen, E. L. (2004). Polaromonas naphthalenivorans sp. nov., a naphthalene-degrading bacterium from naphthalene-contaminated sediment. Int J Syst Evol Microbiol 54, 93-97.

Kang, H. S. \& Lee, S. D. (2009a). Hirschia maritima sp. nov., isolated from seawater. Int J Syst Evol Microbiol 59, 2264-2268.

Kang, H. S. \& Lee, S. D. (2009b). Ponticaulis koreensis gen. nov., sp. nov., a new member of the family Hyphomonadaceae isolated from seawater. Int J Syst Evol Microbiol 59, 2951-2955.

Kim, J. M., Le, N. T., Chung, B. S., Park, J. H., Bae, J.-W., Madsen, E. L. \& Jeon, C. O. (2008). Influence of soil components on the biodegradation of benzene, toluene, ethylbenzene, and o-, m-, and p-xylenes by the newly isolated bacterium Pseudoxanthomonas spadix BD-a59. Appl Environ Microbiol 74, 7313-7320.

Kim, J. M., Lee, S. H., Jung, J. Y. \& Jeon, C. O. (2010). Marinobacterium lutimaris sp. nov., isolated from a tidal flat. Int J Syst Evol Microbiol 60, 1828-1831.

Komagata, K. \& Suzuki, K. (1987). Lipid and cell-wall analysis in bacterial systematics. Methods Microbiol 19, 161-207.

Lai, Q., Yuan, J. \& Shao, Z. (2009). Maribaculum marinum gen. nov., sp. nov., isolated from deep seawater. Int J Syst Evol Microbiol 59, 3083-3087.

Lányí, B. (1987). Classical and rapid identification methods for medically important bacteria. Methods Microbiol 19, 1-67.

Lee, K. B., Liu, C. T., Anzai, Y., Kim, H., Aono, T. \& Oyaizu, H. (2005a). The hierarchical system of the 'Alphaproteobacteria': description of Hyphomonadaceae fam. nov., Xanthobacteraceae fam. nov. and Erythrobacteraceae fam. nov. Int J Syst Evol Microbiol 55, $1907-$ 1919.

Lee, J. C., Jeon, C. O., Lim, J. M., Lee, S. M., Lee, J. M., Song, S. M., Park, D. J., Li, W. J. \& Kim, C. J. (2005b). Halomonas taeanensis sp. nov., a novel moderately halophilic bacterium isolated from a solar saltern in Korea. Int J Syst Evol Microbiol 55, 2027-2032.

Lee, K., Lee, H. K., Choi, T. H. \& Cho, J. C. (2007). Robiginitomaculum antarcticum gen. nov., sp. nov., a member of the family Hyphomonadaceae, from Antarctic seawater. Int J Syst Evol Microbiol 57, 2595-2599.

Lu, S., Park, M., Ro, H.-S., Lee, D. S., Park, W. \& Jeon, C. O. (2006). Analysis of microbial communities using culture-dependent and culture-independent approaches in an anaerobic/aerobic SBR reactor. J Microbiol 44, 155-161.

Minnikin, D. E., Patel, P. V., Alshamaony, L. \& Goodfellow, M. (1977). Polar lipid composition in the classification of Nocardia and related bacteria. Int J Syst Bacteriol 27, 104-117.

Moore, R. L., Weiner, R. M. \& Gebers, R. (1984). Genus Hyphomonas Pongratz 1957 nom. rev. emend., Hyphomonas polymorpha Pongratz 1957 nom. rev. emend., and Hyphomonas neptunium (Leifson 1964) comb. nov. emend. (Hyphomicrobium neptunium). Int J Syst Bacteriol 34, 71-73.

Park, M., Ryu, S. H., Vu, T. H., Ro, H. S., Yun, P. Y. \& Jeon, C. O. (2007). Flavobacterium defluvii sp. nov., isolated from activated sludge. Int J Syst Evol Microbiol 57, 233-237.

Quan, Z.-X., Zeng, D.-N., Xiao, Y.-P., Roh, S. W., Nam, Y.-D., Chang, H.-W., Yoon, J.-H., Oh, H.-M. \& Bae, J.-W. (2009). Henriciella marina 
gen. nov., sp. nov., a novel member of the family Hyphomonadaceae isolated from the East Sea. J Microbiol 47, 156-161.

Rosselló-Mora, R. \& Amann, R. (2001). The species concept for prokaryotes. FEMS Microbiol Rev 25, 39-67.

Sambrook, J. \& Russell, D. W. (2001). Molecular Cloning: a Laboratory Manual, 3rd edn. Cold Spring Harbor, NY: Cold Spring Harbor Laboratory.

Strömpl, C., Hold, G. L., Lünsdorf, H., Graham, J., Gallacher, S., Abraham, W.-R., Moore, E. R. B. \& Timmis, K. N. (2003). Oceanicaulis alexandrii gen. nov., sp. nov., a novel stalked bacterium isolated from a culture of the dinoflagellate Alexandrium tamarense (Lebour) Balech. Int J Syst Evol Microbiol 53, 1901-1906.

Tamaoka, J. \& Komagata, K. (1984). Determination of DNA base composition by reverse-phase high-performance liquid chromatography. FEMS Microbiol Lett 25, 125-128.

Thompson, J. D., Higgins, D. G. \& Gibson, T. J. (1994). CLUSTAL W: improving the sensitivity of progressive multiple sequence alignment through sequence weighting, position-specific gap penalties and weight matrix choice. Nucleic Acids Res 22, 46734680. 